\title{
Facebook: When Education Meets Privacy
}

\author{
Steven Bruneel, Centre for Instructional Psychology and Technology, \\ Kurt De Wit, Office for Educational Policy, \\ Jef C. Verhoeven, Centre for Sociological Research, \\ Jan Elen, Centre for Instructional Psychology and Technology, \\ University of Leuven, Leuven, Belgium
}

\author{
steven.bruneel@ppw.kuleuven.be; kurt.dewit@dowb.kuleuven.be; \\ jef.verhoeven@soc.kuleuven.be; jan.elen@ppw.kuleuven.be
}

\begin{abstract}
The use of social networking sites (SNSs) has become commonplace amongst students. In this research, we aim to shed light upon the educational use and privacy issues on Facebook from the perspective of role theory and reference group theory. 15 bachelor students of the University of Leuven (KU Leuven) in Flanders, Belgium, were interviewed in depth several times during the 2009-2010 academic year. In addition, 143 students completed an online survey concerning their daily ICT use. Our findings confirm the enormous popularity of SNSs amongst contemporary students. Findings also suggest that students make a clear distinction between ICT use for study and non-study related purposes. Three categories of students arise concerning students' answers on the question of whether Facebook possesses educational possibilities: the indifferents, the approvers, and the supporters. No interviewee would accept a friendship request from a faculty member, partly based on an awareness of the consequences of too much self-disclosure on Facebook. Three explanations, inspired by role theory and reference group theory, are given to frame this denial: firstly, that students identify themselves with different reference groups; secondly, in reference group theory, that the behavior of a person is consistent with the expectations of the peer group; and finally, inspired by role theory, that being a faculty member's friend is seen as a role conflict.
\end{abstract}

Keywords: Social networking sites, educational use, university, role theory, reference group theory

\section{Introduction}

In 1997, SixDegrees.com was launched, a website now believed to be a precursor of more current social networking sites such as Facebook, MySpace, LinkedIn, Twitter, and Hyves. Today the use of social networking sites (hence SNSs) has become commonplace amongst youngsters and

Material published as part of this publication, either on-line or in print, is copyrighted by the Informing Science Institute. Permission to make digital or paper copy of part or all of these works for personal or classroom use is granted without fee provided that the copies are not made or distributed for profit or commercial advantage AND that copies 1) bear this notice in full and 2) give the full citation on the first page. It is permissible to abstract these works so long as credit is given. To copy in all other cases or to republish or to post on a server or to redistribute to lists requires specific permission and payment of a fee. Contact Publisher@InformingScience.org to request redistribution permission. young adults. Tufekci (2008) found that between $80 \%$ and $90 \%$ of college students are a member of at least one SNS. The first SNS that gained worldwide popularity was MySpace. Barely four years after its launch in 2003, it had become by far the most adopted SNS amongst youngsters, with 100 million users and attracting 230,000 new users each day at some point in time (Lenhart \& Madden, 2007; Sellers, 2006). Ac- 
cording to Hinduja and Patchin (2008), this popularity is "due in large part not because of innovative functionality and utility, but because it centralized many attractive functions that were already a part of other social networking sites in a user-friendly way" (p. 130). Not surprisingly, MySpace is not the only SNS available (for an overview, see Boyd \& Ellison, 2007); Facebook seems to be the most popular for people of all ages (Doughtery, 2010; see also Judd \& Kennedy, 2010). In a follow-up study in September 2009 by Lenhart, Purcell, Smith, and Zickuhr (2010), $71 \%$ of a sample of American young adults (between 18 and 29 years old) owned a Facebook account, 66\% a MySpace account, and 7\% a LinkedIn account. In July 2010, Facebook reached over 500 million active users (Facebook, 2010). In Belgium alone, more than 4.6 million active users (of the 7 million who surf the Internet) have a profile on Facebook (Socialbakers, 2012).

In this contribution, the focus is upon Facebook. Taking into account Facebook's current popularity amongst college students, much research has been established to explore the possibility of using Facebook as an educational tool. Such interest is, of course, not new. Ever since the introduction of television into schools and the increasing popularity of computers and video games, scholars have been paying attention to education that is in some way technologically facilitated (Cuban, 1986). So is the case with regard to SNSs: a lot of research concerning the SNSeducation relationship has been conducted over the last years (e.g. Anderson, 2007; Anderson \& Dron, 2011; Bugeja, 2006; Kirschner \& Karpinski, 2010; Mason \& Rennie, 2008; Mazman \& Usluel, 2010; Roblyer, McDaniel, Webb, Herman, \& Witty, 2010; Sandars \& Schroter, 2007; Selwyn, 2009) and resulted in some systematic reviews (e.g. Manca \& Ranieri, 2013). Moreover, some of them argue that SNSs entail a lot of educational possibilities (e.g. Greenhow, 2011; Halverson, 2011; Lee \& McLoughlin, 2008; Selwyn, 2007). For instance, Lee and McLoughlin (2008) claim that SNSs are pedagogical tools, because one can use them for content creation, collaborative information discovery and sharing, and knowledge and information aggregation and modification. Despite high expectancies with respect to the potential of Facebook, current research on the relationship between Facebook use and academic achievement shows no - or even a negative - relationship (e.g., Kirschner \& Karpinski, 2010; Pasek, More, \& Hargittai, 2009). Yet, what seems for the most part to be ignored in the research literature regarding SNSs, in our view, is the willingness of students to accept Facebook as an educational tool, a tool that is used in an instructional context to foster their learning processes (Roblyer et al., 2010). Therefore, we delve into students' own, self-reported perspectives regarding the use of Facebook in education, as further insight into students' opinions, to add value within this currently popular research domain. In case students do not appreciate the use of Facebook as a tool for educational purposes, it can be expected that the added value of Facebook will be rather limited (cf. Perkins \& Turpen, 2009).

After this short introduction on the popularity of Facebook, this article briefly presents role theory and reference group theory, as we will use them as an interpretive framework. This is followed by a literature overview of the steady rise of Facebook, and the willingness of students and faculty members to use Facebook for educational purposes. After elaborating on the methods adopted, we present an overview of the results. First, some answers will be given on questions about the popularity of Facebook in comparison with other SNSs among students. Second, we will focus on the possible educational function of Facebook from the standpoint of the students. Third, we will describe the consequences of the main function of Facebook for the relationship between students and faculty. We end with a discussion and conclusion in which we evaluate to what extent our results can be explained by role theory and reference group theory, followed by some recommendations. 


\section{Research Purpose}

Contemporary teenagers and young adults grow up in a technology oriented society. The question in which way students use these technological devices (computer use including SNS, mobile phone, and mobile learning devices, etc.) in relation to their study process is at the core of our study. In this article in particular, we focus on the use of SNSs and students' willingness to use SNS, i.e. Facebook, for educational purposes. We consciously chose to interview students who already studied one year at the university, because they already have some experience with these technologies during their study process.

Even more importantly, our goal was to frame and explain our findings within role theory and reference group theory because not much attention is paid in the current literature concerning the use of SNSs to these theories. It is our intention to show how these theories help to understand why students use SNSs the way they do.

At the KU Leuven, a course transcending document is available to determine all the intended learning outcomes (please see http://www.kuleuven.be/education/KULeuvenVision of teaching and learing-2009.pdf). Intended learning outcomes (ILOs) are statements of what a learner is expected to know, understand, and be able to do at the end of a period of learning. One of the ILOs which is of high importance, and what we therefore want to stress in this research, is "the responsibility for their [students] own learning process with a view to understanding phenomena, exploring the cultural tradition and participating in society" (KU Leuven, 2009). Further in this article, we state that some results can be linked with this competence.

\section{Theoretical Background}

\section{Role Theory and Reference Group Theory}

While a lot of research has already been completed on the educational potential of SNSs, role theory and reference group theory have barely been applied as a framework to better understand the relationship. One of the few examples is the research by Minocha, Schroeder, and Schneider (2011), who based their research about social software in higher education on role theory. But different to their research, which focused on educator roles in a social software context, our research deals with students' use of SNSs.

Role theory “....is designed to explain how individuals who occupy particular social positions are expected to behave and how they expect others to behave" (Hindin, 2007, p. 1). It is assumed that people behave predictably; an individual's behavior is context-specific and based on his or her social position and situation. In other words, every person plays a social role. The role player experiences a kind of pressure on his or her behaviour, but it is clear that this pressure is different, dependent on the expectations of the society and the sanctions established to punish those who deviate from these expectations. Dahrendorf (1968) distinguishes three types of expectations, each upheld by a different kind of sanction: 1) must-expectations, sanctioned by negative sanctions (for instance by court); 2) shall- expectations, sanctioned by negative sanctions such as social exclusion; and 3) can-expectations, supported by positive sanctions. The final sanction type can be seen as a reward for actors who are doing what they are expected to do. For instance, students who violate the privacy regulations of an SNS may be sanctioned by court; students who frequently do not answer questions of friends sent by SNS might be excluded from the group; and students who are prepared to help friends with PC problems may expect to receive much sympathy from those who need support. Despite the well-defined roles, people can experience contradictory or incompatible expectations, based on the roles they occupy. These role conflicts can arise across two or more roles and within one role (see also Biddle \& Thomas, 1966; Lynch, 
2007). Playing a role also means that an actor is aware of others and that the actor may (or not) refer to other actors who might judge whether he or she is acting according to their expectations.

An important addition to role theory is offered by reference group theory. Whereas in role theory the individual is taken as the starting point of analysis, reference group theory starts from the group for the understanding and explanation of social behaviour. Shibutani (1986) defines a reference group as "... that social unit whose culture is used as a frame of reference in defining a succession of situations. It could be a community, a social world, an organized group, or a small circle of personal friends" (p. 113). These reference groups can be an important support for the actor to "take the role of the other", as Mead (1964) has defined this process. In society, the pressure on the actor might be so strong "...that the behavior of a person placed under such crosspressure will be consistent with the expectations of the group which serves as a reference point at the time" (Mirande, 1968, p. 572). However, this is not true for all reference groups. An important reference group may be the peer group, certainly for youngsters, but it is not certain that all members of the peer group will be regarded as a positive reference group by students using SNSs or virtual learning platforms. It will depend on the kind of expectations of the significant others in the peer group and the sanctions they might use for establishing a particular pattern of behaviour (Merton \& Lazarsfeld, 1950). Indeed, although SNSs spread very fast, it is not unthinkable that youngsters in some schools did not immediately join this development. Teachers and/or parents were not always enthusiastic about such hype and may have warned against youngsters joining one of these sites too readily. Since teachers and parents are certainly for most young people significant others, i.e., people to whom an actor is referring for legitimating his or her behaviour, it happened that under influence of teachers and/or parents youngsters became temporary resisters. In the next two sections, we give a short overview of the method of Facebook, and to what extent students use Facebook for educational reasons.

\section{Method of Facebook}

Facebook is one of the most popular SNSs. Many definitions of SNSs are available in current research. According to Lenhart and Madden (2007), "SNS is an online place where a user can create a profile and build a personal network that connects him or her to other users" (p. 1). Boyd and Ellison (2007) define SNSs as "web-based services that allow individuals to construct a public or semi-public profile within a bounded system, articulate a list of other users with whom they share a connection and view and traverse their list of connections and those made by others within the system" (p. 211). Finally, Selwyn (2009) defines SNS as “... personal and personalisable spaces for online conversations and sharing of content based typically on the maintenance and sharing of 'profiles', where individual users can represent themselves to other users through the display of personal information, interests, photographs, social networks and so on" (p. 157).

There is some agreement that SNSs are largely about making virtual connections between people, which may or may not overlap with connections in the physical world. As the introduction has shown, Facebook is only (but notwithstanding a very influential) part of a much broader field of SNSs. Facebook was founded in February 2004 by Mark Zuckerberg, student at Harvard University. At that moment, Facebook.com was an application only accessible to people with a Harvard e-mail address. However, Facebook soon opened its doors to students of other universities (Boyd \& Ellison, 2007; Cassidy, 2006; Hirschorn, 2007). Initially, Facebook users were only allowed to make contacts with students of their own college because this requirement "kept the site relatively closed and contributed to users' perceptions of the site as an intimate, private community" (Boyd \& Ellison, 2007, p. 218). In 2005, Facebook expanded gradually, towards high schools, towards companies, and later everyone with an e-mail address was allowed to join. This gradual expansion was followed by an exponential growth of subscribers - by the end of 2005, Facebook 
had 5.5 million active users, in July 2010, more than half a billion, and in August 2012 more than 893 million (Cassidy, 2006; Facebook, 2010; Socialbakers, 2012).

When joining Facebook, every new user is asked to make a profile. This profile, acting as a digital representation of oneself (Boyd, 2008), can be as extensive (or brief) as one wants, providing basic personal data such as sex, date of birth, address, siblings and interests; joining networks such as the college one attends or the company one works for; displaying pages ("groups") one is connected to (e.g. 'X joined the group 'We love Justin Bieber'” ); etc. Once a member on Facebook, one can connect with other members by sending a friend request. If the other party accepts the request, a friendship is formed and displayed in the friends list on the homepage of both users. Based on these friendships, Facebook automatically suggests other possible friends one may have in common with already established friends. These virtual friendships are still an important part of the core business of Facebook, as reflected in Facebook's mission, "to give people the power to share and make the world more open and connected" (Facebook, 2010, p. 1). A further possibility is the capability to upload photographs, and 'tag' the friends that appear in them. Another well-known possibility is that of posting wall posts on one's 'wall', an interactive section on every user's profile page that allows friends to post wall posts for everyone to see. Finally, one can create or apply to join social interest groups and play games (e.g., Farmville) (cf. Mazman \& Usluel, 2010).

Given these characteristics and possibilities of Facebook, one can wonder why Facebook is so popular. Indeed, the characteristics listed above can be found on other SNSs as well. For instance, on MySpace one has the possibility to use the 'stream' page (similar to Facebook's wall), to tag photographs, to make friends, etc. One of the features that differentiates Facebook from other SNSs is the way in which it manages privacy (Boyd \& Ellison, 2007). On Facebook you (normally) know who you are talking to, whereas on MySpace people might not always be who they claim to be.

Facebook already has a long tradition of changing their privacy settings (for an overview see Boyd \& Hargittai, 2010). Despite widespread assumptions that youngsters do not care about their privacy on the internet (cf. CMU, 2010), Boyd and Hargittai (2010) found students do care about their privacy settings. Making use of the 2009 data set among 1,115 first year students and the follow-up study undertaken in 2010 among 495 participants, they found the students' engagement with privacy settings increased significantly between 2009 and 2010 . Whereas in $2009,9 \%$ of all Facebook users in Boyd and Hargittai's dataset never changed their privacy settings, only 2\% never changed them in 2010. The dataset of 2010 also indicated that $51 \%$ of all Facebook users changed their privacy settings four times or more, whereas only $24 \%$ did so in 2009 . Another study by Fogel and Nehmad (2009), making use of questionnaires answered by 205 undergraduate students, shows that Facebook had greater trust ratings than MySpace. The authors think that "this may be because up until late 2006, Facebook was restricted to students while MySpace was open to all Internet users" (Fogel \& Nehmad , 2009, p. 159). In the literature, some reasons are proposed as to why some users restrict access to their profiles, while others do not. Waters and Ackerman (2011) conducted a survey among 95 undergraduate students of an university in the United States and found four main motivations to disclose private information on Facebook: 1) sharing private information is seen as a fun and enjoyable activity; 2) it is seen "as a way to store information that is meaningful to them" (p. 110); 3) private information might also help to keep up with trends; and 4) a last motivation was to show off their popularity. Boyd (2008 as cited in Boyd \& Hargittai, 2010) found that teenagers were concerned about people who held immediate power over them (e.g., parents, teachers). Raynes-Goldie (2010) argues that social privacy is of greater concern than institutional privacy. In other words, Facebook users are more concerned about being exposed to people that they know than having their data accessed by governments and corporations. 


\section{Students' Willingness to use Facebook for Educational Reasons}

Above we have outlined the features of Facebook and made the observation that Facebook users seem to take care of their privacy settings. Most of them are well aware that all their (Facebook) friends can read their wall posts, which obviously leads to a more cautious attitude. Besides the polemic concerning privacy issues on Facebook, we also want to shed light on a related theme, namely the willingness of students to use Facebook for educational activities. Here, willingness is defined as a free choice to do or use something without reluctance (BrainyQuote, 2010). Besides our narrowed focus on students' willingness in this article, we want to stress that our interpretation of the educational use of Facebook is not just on students' willingness. In this research, we define 'the educational use' of Facebook (and more general, of SNSs) as any activity on Facebook that is (in)directly related to their study process (e.g., communication about practical or content activities, content related questions, etc.). The research based on students' willingness to implement Facebook in their educational activities is not unanimous in regard to the opinions of students towards allowing faculty members to enter their online, virtual Facebook life.

Some research provides evidence that this definitely is the case, as shown in Table 1.

Table 1: Research overview of students' willingness to use Facebook for educational purposes

\begin{tabular}{|c|c|c|}
\hline Research & Sample & Results \\
\hline Hewitt \& Forte (2006) & $\begin{array}{l}136 \text { undergraduate students } \\
\text { Survey }\end{array}$ & $\begin{array}{l}66 \% \text { don't have objection to } \\
\text { faculty members' presence on } \\
\text { Facebook }\end{array}$ \\
\hline $\begin{array}{l}\text { Kabilan, Ahmad, \& Abidin } \\
\text { (2010) }\end{array}$ & $\begin{array}{l}300 \text { undergraduate students } \\
\text { Survey }\end{array}$ & $\begin{array}{l}77.8 \% \text { agree that Facebook could } \\
\text { be an effective environment for } \\
\text { enhancing English communica- } \\
\text { tion }\end{array}$ \\
\hline $\begin{array}{l}\text { Mazer, Murphy, \& Simonds } \\
\text { (2007) }\end{array}$ & $\begin{array}{l}133 \text { undergraduate students } \\
\text { Experiment }\end{array}$ & $\begin{array}{l}61 \% \text { find it somewhat acceptable } \\
\text { for faculty members to be on } \\
\text { Facebook }\end{array}$ \\
\hline $\begin{array}{l}\text { Pimmer, Linxen, \& Gröhbiel } \\
\text { (2012) }\end{array}$ & $\begin{array}{l}\text { Focus groups composed of } 30 \\
\text { medical students and } 13 \text { faculty }\end{array}$ & $\begin{array}{l}\text { A "medical" site on Facebook is } \\
\text { used to exchange medical infor- } \\
\text { mation }\end{array}$ \\
\hline Roblyer et al. (2010) & $\begin{array}{l}120 \text { university students } \\
\text { Survey }\end{array}$ & $\begin{array}{l}46.7 \% \text { are favorable to an educa- } \\
\text { tional use of Facebook }\end{array}$ \\
\hline
\end{tabular}

For instance, Hewitt and Forte (2006) surveyed 136 students and noticed that of the 102 students who responded to the question on whether or not it is acceptable for faculty to be on Facebook, $66 \%$ found this to be acceptable. Similar conclusions were drawn in the research of Mazer, Murphy, and Simonds (2007), who found that $61 \%$ of 133 undergraduate students found it, to a more or lesser extent, appropriate for faculty members to be on Facebook. In a similar vein, Roblyer et al. (2010) held an online survey among 120 students about the use and perception of SNSs. They observed that $46.7 \%$ of the students answered the question on whether it would be convenient to use Facebook in education in a positive way. Kabilan, Ahmad, and Abidin (2010) held a survey among 300 undergraduate students of a Malaysian university; they concluded that "students believed Facebook could be utilized as an online environment to facilitate the learning of English" 
(p. 179). Pimmer, Linxen, and Gröhbiel (2012) organized focus groups among 30 medical students and 13 medical faculty in Nepal. A particular medical Facebook site played an important role. They concluded that this site was used as a typical e-learning platform in a resource-limited environment (developing country). Nevertheless, the faculty did not integrate these Facebook activities in formal teaching.

Other research listed in Table 2 leads to the observation that the majority of students are not fond of the idea of letting educational matters merge into their Facebook activity.

Table 2: Research overview of students' denial to use Facebook for educational purposes

\begin{tabular}{lll}
\hline Research & Sample & Results \\
\hline Chu \& Meulemans (2008) & $\begin{array}{l}89 \text { university students } \\
\text { Survey \& focus group }\end{array}$ & $\begin{array}{l}\text { E-mail, instead of Facebook, is } \\
\text { the most appropriate way to } \\
\text { communicate with faculty mem- } \\
\text { bers }\end{array}$ \\
Madge et al. (2009) & $\begin{array}{l}213 \text { undergraduate students } \\
\text { Survey }\end{array}$ & $\begin{array}{l}36 \% \text { agree that tutors can use } \\
\text { Facebook for educational pur- } \\
\text { poses }\end{array}$ \\
West et al. (2009) & $\begin{array}{l}\text { Facebook is a part of their private } \\
\text { lives }\end{array}$ \\
\hline
\end{tabular}

In a study of 89 participating students in an American university, Chu and Meulemans (2008) found that students see e-mail as the more appropriate way to communicate with professors rather than using Facebook or MySpace. Madge, Meek, Wellens, and Hooley (2009) showed in a study among 213 UK students that a considerable group (41\%) "would not like tutors to contact them via Facebook for formal teaching purposes" (p. 150). Related to this, these researchers found that only $36 \%$ positively answered the question on whether or not it is appropriate for teachers to use Facebook for educational purposes. Furthermore, Madge et al. (2009) found that students actually use Facebook more for socializing and talking to friends about education-related matters than for doing formal educative work (e.g., composing group papers). For instance, they found that only $7 \%$ reported "that they had used Facebook as a formal part of their learning experience" (Madge et al., 2009, p. 149). West, Lewis, and Currie (2009) examined the extent to which older adults and specifically parents are accepted as Facebook friends. They interviewed 16 students between the ages of 21 and 26, and found that the majority of them were inclined to consider Facebook (as a tool) as being part of their private lives.

In our view, we can situate these results using theories of the adolescents' psycho-social development. Results of West et al. (2009) show that peers are important reference groups. There are many reasons to expect college peers to function as points of anchorage in many areas. In other words, we can state that peers serve as sources of validation for new ideas and perspectives (cf. J. De Wit, Van Der Veer, \& Slot, 2005).

When viewing this from the perspectives of role theory and reference group theory, our focus is on two main themes: we want to unravel the polemic about the privacy issues on Facebook - in other words, we want to make clear to what extent students are aware of the danger of making personal data public - and we are interested to know whether or not those privacy issues affect students' willingness to accept friendship requests from faculty members. This data can also be used to underpin the theme of whether or not students use Facebook for educational purposes. Hence, the following research question is addressed: How do role theory and reference group theory relate to privacy issues on Facebook, and students' willingness to accept friendship requests of faculty members on Facebook? 


\section{Methodology}

\section{Instrument}

This research is part of a larger study concerning the daily study-related ICT use of Flemish students. For this global study, data was gathered through the use of a mixed method design. This means that multiple methods, qualitative and quantitative, were used to gather data (i.e., Web survey and in depth interviews). To use the words of Denzin $(1970 ; 1978)$, our research model is a model of methodological triangulation (see Table 3). This label is also used by Hammersley (1996). He refers to triangulation as the use of quantitative research to corroborate qualitative research findings or vice versa.

First, the qualitative part of this study contains interviews of bachelor degree students of the KU Leuven (Flanders/Belgium). We chose to interview our respondents multiple times during the academic year in order to avoid disregarding (possible) different characteristics in their daily ICT use, and more specific, in their usage of Facebook: indeed, we are aware that fluctuations can arise in the amount of ICT use according to students' experienced amount of workload, and more in general not to disregard possible 'hypes' (e.g., Photoshop, Farmville, Cityville). Furthermore, during the interviews, students' willingness to accept faculty members' friendship requests can also be discussed. The interviews have a semi-structured character. Thus, respondents were given the opportunity to speak freely about their experiences, and to give as many examples as they wanted. Furthermore, some 'main' questions permit us to compare more easily students' meanings and experiences.

The interviews were conducted as much as possible at the student's residence for two reasons: to create an environment where students felt comfortable and to give the opportunity to the interviewer to check the current technologies used by the respondents.

Prior to the interviews, two focus groups (The first focus group consisted of 4 students ( 3 boys, 1 girl; response rate $=9.8 \%$ ) of the Faculty Science, Engineering and Technology of the KU Leuven. The second focus group consisted of 5 students ( 5 girls; response rate $=12.5 \%$ ) of the Faculty of Arts and the Faculty of Social Sciences) were organized to test the interview guidelines and to familiarize the researchers with students' vocabulary related to their ICT use. These focus groups were interviewed during September-October 2009. The rationale behind choosing bachelor degree students as respondents is that college students tend to easily adopt new technologies (Pempek, Yermolayeva \& Calvert, 2009).

A second part of data collection consisted of two online surveys. Each survey consisted of two separate sections. In the first section, demographic characteristics were collected through four questions. The second section contained 24 questions and aimed at gathering the respondents' use of their personal computer. In fact, the respondents were asked to write up a diary with respect to their ICT-use.

\section{Procedure}

Data collection was undertaken during the 2009-2010 academic year. For both the in-depth interviews and the Web survey, students were recruited at random and their participation was voluntary. Students were sent an e-mail with an invitation to participate in this research. A reminder was sent 10 days after the first invitation.

For the qualitative part of this study, 15 (of 87 invited students, response rate $=17.24 \%$ ) students from different study programs at the KU Leuven in Flanders/Belgium were interviewed in depth several times during the academic year 2009-2010. Five men $(33.33 \%)$ and ten women $(66.67 \%)$ participated, and none of them participated in the (prior) focus groups. Respondents were inter- 
viewed up to four times in order to observe the (possible) evolution of ICT-use by these students, resulting in 36 in-depth interviews. Concretely, data collection started in October 2009 and ended in May 2010 (see Table 3). Respondents were interviewed four times (due to respondents' workload, some of them were only interviewed two or three times) and not during an examination period (i.e., January or June). The mean duration was 30 minutes. All interviews (also of the focus groups) were digitally recorded (with interviewees' permission) and transcribed verbatim. An overview of this procedure can be found in Table 3.

Table 3: Map of methodological triangulation

\begin{tabular}{lll}
\hline Time line & Qualitative methods & Quantitative method \\
\hline September-October 2009 & 2 focus groups & \\
October 2009 & In depth interviews & \\
November-December 2009 & In depth interviews & Web survey 1 \\
February 2010 & In depth interviews & Web survey 2 \\
March 2010 & & \\
April-May 2010 & In depth interviews & \\
\hline
\end{tabular}

These different steps were taken because we wanted to obtain reliable and valid observations. Denzin (1978) defines a reliable observation as one that "... is not biased by idiosyncrasies of the observer, a research instrument, or a subject, or by constraints of time and place" (p.105). Although it is not always possible to escape from these pitfalls, our method of frequent interviewing in the natural environment of the students (data triangulation) has most probably supported making our observations as reliable as possible. Students had the opportunity to reflect on the use of SNS and PC in the concrete situation in which they study. Moreover, our preparatory work with focus groups has opened the field of vision of the interviewer for all kind of opinions of students concerning the use of PC and SNSs. The validity of the collected information among the students was also supported by these focus group experiences. A sound knowledge of the language of youngsters in relation to ICT will contribute to a valid understanding of what they mean and is also a help to check whether the accounts given by the interviewees are representing what they want to tell.

For the quantitative part of this study, a Web survey was conducted at two different times. The first Web survey was held in November 2009 (further referred to as Web Survey 1) and the second in March 2010 (further referred to as Web Survey 2). Several hundred students, drawn at random from university lists, received a questionnaire online. During the survey held in November 2009, 67 students participated. The sample consisted of 26 male participants (38.81\%) and 41 female participants (61.19\%). In March 2010, 73 students collaborated. This sample consisted of 13 males $(17.80 \%)$ and 60 females $(82.19 \%)$. The Web survey was kept open to participants for one week.

\section{Data Analysis}

Initially, it was our goal to merge both Web surveys. However, after significant differences appeared with regard to gender and faculty (respectively $\chi^{2}=7.344, p=0.007, d f=1$ and $\chi^{2}=$ 27.042, $p=0.008, d f=12$ ), we decided to distinguish the results of Web Survey 1 and Web Survey 2 . Note that faculty should be interpreted here as an organizational unit of the university, and not as teaching staff. 
The data analysis of this mixed method study is a result of our concern for reliability and validity, which can be seen, first and foremost, in the use of methodological triangulation and secondly in the use of two researchers for coding the interviews. A qualitative data analysis tool, NVivo 8.0, was used to assist with the coding of the data into themes (Bazeley, 2007). Before the coding process, all transcripts were sent to the respondents for verification in order to meet a specific validity level. We wanted to know whether the account we had collected represented what the interviewee wanted to tell. The coding process started with the readings of all transcribed interviews in their entirety by two researchers each time. After a first reading, some 'basic' themes emerged from a closer reading of the data and were arranged in a tree diagram. This tree diagram was used during the coding phase. More concretely, in each case the interviews were coded by two researchers and followed by comparing each other's coding. Given this method, we did not measure inter-observer reliability because each interview was coded by two researchers. When the agreement was low, codes were refined so some modifications were introduced. Throughout the analytic process, memos were written on codes. Finally, we arrived at a more detailed tree diagram in which all qualitative data was coded.

Data from the online survey was analysed using SAS 9.3. Besides the enunciation of the quantitative data into tables and figures, chi-square tests were conducted to find significant relationships between variables.

\section{Results}

In this results section, we start with an overview of Facebook's popularity amongst students. Secondly, we sum up some educational possibilities of Facebook as suggested by our respondents, and we end with students' perspectives towards faculty members' presence and privacy issues on Facebook.

\section{Facebook's Popularity Amongst Students}

As cited above, our results confirm the enormous popularity of SNSs, and Facebook in particular, amongst students. $83.58 \%$ of Web Survey 1 students and $82.90 \%$ of Web Survey 2 students have a Facebook account. Moreover $92.50 \%$ of Web Survey 1 students and $87.67 \%$ of Web Survey 2 students are members of at least 2 SNSs (respectively 62 of 67 Web Survey 1 students and 64 of 73 Web Survey 2 students); Windows Live Messenger seems to be even more popular than Facebook among Flemish students (see Table 4).

Table 4: Membership of social networking sites (Web Survey 2) $(\mathrm{N}=73)$

\begin{tabular}{lr}
\hline Social Network & Percent* \\
\hline MSN Messenger & 90.4 \\
Facebook & 83.6 \\
Skype & 39.7 \\
Netlog & 21.9 \\
Twitter & 9.6 \\
MySpace & 8.2 \\
Hyves & 6.8 \\
Skyrock & 1.4 \\
\hline
\end{tabular}

*Because students could give more than one answer, the percentage of each SNS is calculated on 73 .

Furthermore, on a Monday students with a Windows Live Messenger account are connected with the Windows Live Messenger website an average of 174 minutes in Web Survey 1 or 164 in Web 
Survey 2. This is considerably more than other SNSs: students reported they were connected an average of respectively 114 or 95 minutes on Skype and an average of respectively 89 or 91 minutes on Facebook (see Figure 1). 'Connected' in this context does not mean that users actively use the programme mentioned. However, we suggest that students are more 'active' on Facebook (cf., infra) in comparison with Windows Live Messenger and Skype because these final two SNSs are, in essence, 'chat' programmes and were much less used by students on the observation day. In Web Survey $183.6 \%$ of the students used Facebook, whereas only $53.7 \%$ used Windows Messenger, $11.9 \%$ Skype, and 16.4\% Netlog. In Web Survey 2 these figures were respectively $67.1 \%, 38.4 \%$ and $6.8 \%$. Myspace and Twitter did only attract a few students, and so was Netlog in Web Survey 2. The two Web Surveys were conducted during periods when students did not have to prepare for or sit exams.

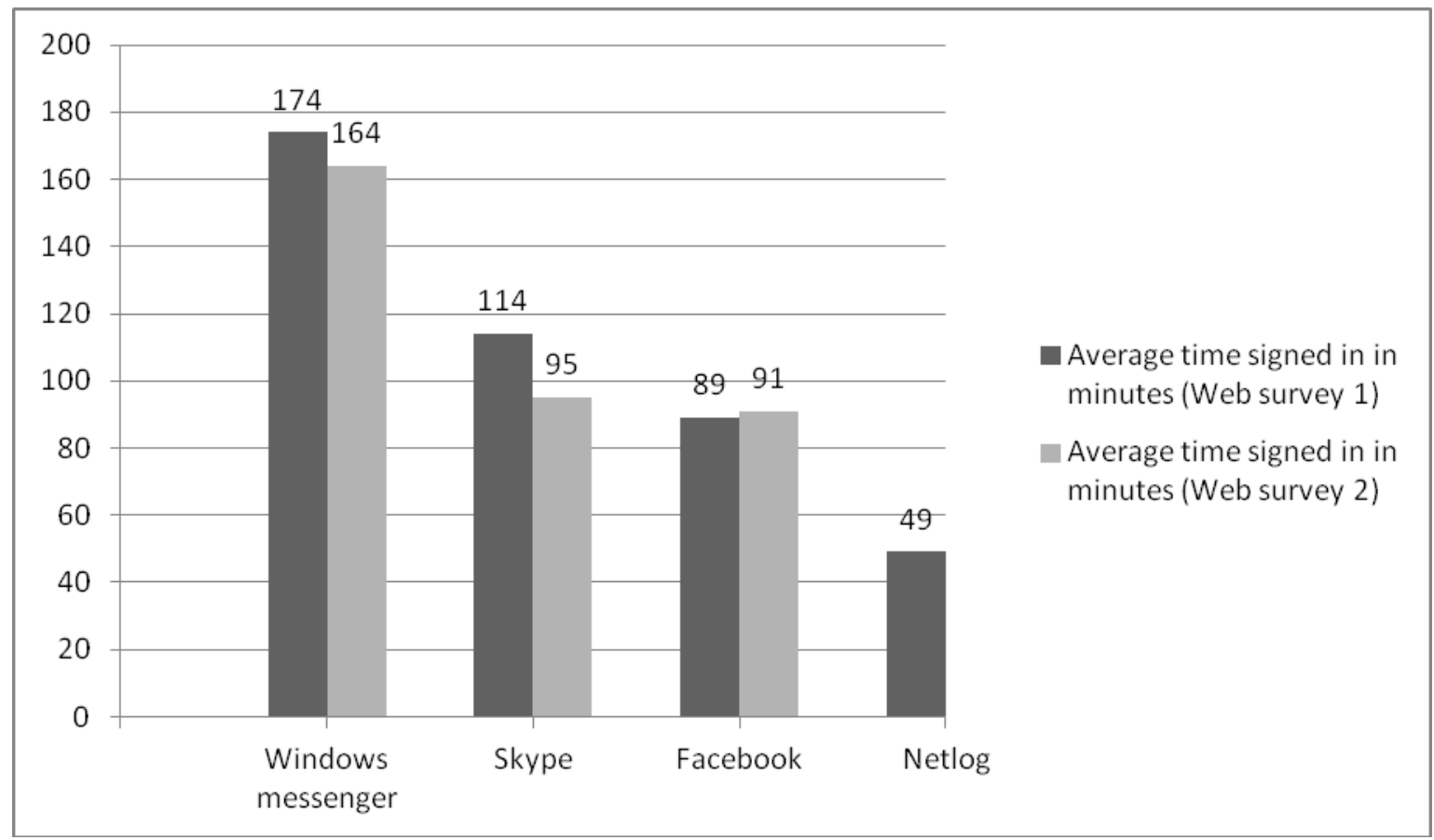

Figure 1: Results of Web Survey 1 and Web Survey 2 for the question: How long were you signed in in each SNS?

The often mentioned gender difference among those who are using ICT instruments (van Dijk, 2006) is not observed in this study: men and women are equally members of Facebook (Web Survey $1: \mathrm{p}=.42$ (Fisher's exact test) ; Web Survey 2: $\mathrm{p}=1.0$ (Fisher's exact test)), Messenger (Web Survey 1: $\chi^{2}=3.59 ; \mathrm{p}=.06$; Web Survey 2: $\mathrm{p}=.10$ (Fisher's exact test)), Netlog (Web Survey 1: $\mathrm{p}=.73$ (Fisher's exact test); Web Survey 2: $\mathrm{p}=.72$ (Fisher's exact test)) or Skype (Web Survey 1: $\mathrm{p}=.73$ (Fisher's exact test); Web Survey $2: \chi^{2}=0.0106 ; \mathrm{p}=.92$ ), have an equal proportion using these social networking sites, and spend on average the same time on each of these social networking sites on our day of observation. Social networking sites seem equally liked by male and female students. Similar results were found by Jones, Ramanau, Cross and Healing (2010), who conducted a survey among 596 first-year students at five universities in England. They found that "gender differences did not appear to be quite as pronounced and there were no statistically significant differences in terms of the frequency of participation in social networks" (p. 728). Our data also show that on the days of observation there is no difference between science students and humanities students as far as their membership of these social network sites is concerned, the use of them, and the time spent on these networks. The significance of the 
differences was calculated using $\chi^{2}$ test, Fisher's exact test, or t-test. These observations are made in Web Survey 1 and Web Survey 2. In Web Survey 1 more science students seem to be a member of Messenger $(\mathrm{p}=.016$ (Fisher's exact test)) and consequently used Messenger more than humanities students $\left(\chi^{2}=6.29 ; p=.01\right)$. Why this is so, is not clear.

The same trend was confirmed in a survey in 2009 among freshmen $(\mathrm{N}=1529)$ at the same university (K. De Wit, Heerwegh \& Verhoeven, 2012). The researchers asked the students whether they could create an account on SNSs (average score $=4.72$ out of 5) and whether they could manage this account later on (average score $=4.65$ out of 5). No difference was observed between male and female students for creating an account $(\mathrm{t}=1.79 ; \mathrm{p}=.074)$ or between humanities and science students $(\mathrm{t}=1.48 ; \mathrm{p}=.139)$, or for managing the account (respectively $\mathrm{t}=1.61 ; \mathrm{p}=.107$; $\mathrm{t}=0.39 ; \mathrm{p}=.696)$.

Interesting is the observation that Facebook members use more SNSs than the non-members of Facebook on the day of observation (Web Survey 1: $\mathrm{p}=.0005$ (Fisher's exact test); Web Survey $2: \mathrm{p}=.001$ (Fisher's exact test)). Web Survey 2 shows that the more SNSs are used the more time students spent on Facebook $(\mathrm{t}=-2.93 ; \mathrm{p}=.005)$ or Messenger $(\mathrm{t}=-5.01 ; \mathrm{p}<.0001)$. The use of one SNS seems to stimulate students to use more than one SNS.

\section{Content}

\section{Perceived Educational Possibilities of Facebook}

SNSs like Facebook are normally established as online places for virtual contact. Facebook (2011) establishes itself as a tool that "helps you connect and share with the people in your life". Despite this manner of propagation, it is common knowledge that tools are not always used in the way they are intended (Zydney, 2008), and hence it might be that students, for example, use Facebook educationally. To shed more light on this topic, we asked our respondents why they visited Facebook. Most students spend time on Facebook in order to maintain contact with friends (Figure 2): they look at new pictures, check what their friends are doing, and write wall posts on their friends' walls.

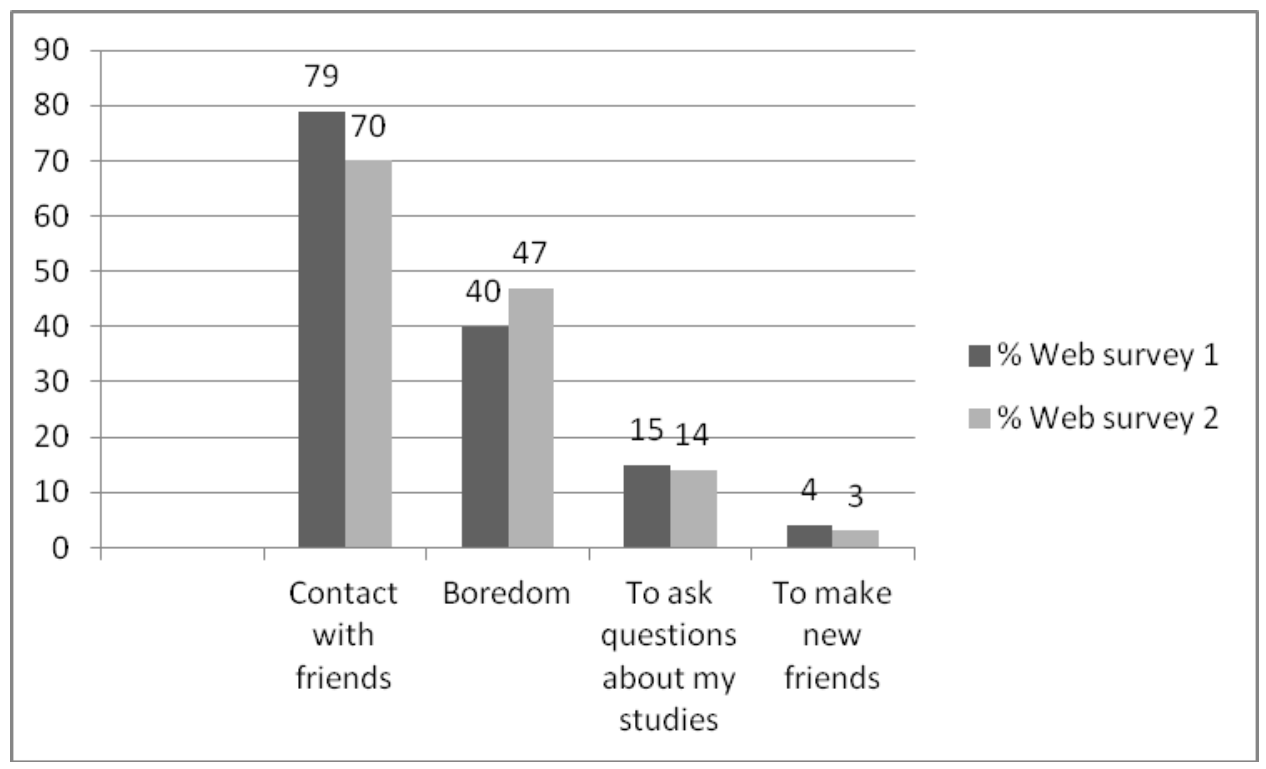

Figure 2: Results for the question: What is/are the reason(s) why you visited SNSs today? (Web Survey 1 N = 67; Web Survey 2 N = 73 
There is no significant difference between male and female students or between science and humanities students as far as the different motivations for using SNSs are concerned. In both surveys most students see the main motivation for using SNSs to keep contact with friends, followed by the use of SNSs in order to escape from boredom, asking questions about studies, and a very small part of them use SNSs to make new friends, on the day of observation. The data also show that the more SNSs students use on the day of observation the more they use it to have contact with friends (Web Survey 1: $\chi^{2}=8.806 ; \mathrm{p}=0.003$; Web Survey 2: $\chi^{2}=8.95 ; \mathrm{p}=0.003$ ), and in Web Survey 1 also to kill boredom $\left(\chi^{2}=4.403 ; \mathrm{p}=0.036\right)$.

Some students also seem to use Facebook to discuss educational matters; $13.3 \%$ of Web Survey 1 students and $13.8 \%$ of Web Survey 2 point out that they used Facebook, on the day of observation, to ask (practical) questions related to their study (cf., one of the ILOs that is mentioned before).

As we now turn to the results of the qualitative part of this study, similar results are found in comparison with the quantitative part:

Interviewer: 'And what is the specific reason?'

Respondent 12: 'Just to stay in contact with everyone'.

Interviewer: 'What are you doing on Facebook?'

Respondent 7: 'Uhm too much actually. I use it as my e-mail, for example friends who are abroad. (...) And I use it mostly if I have too much time, I watch what other people are doing at that moment'.

When looking at particular reasons for students visiting Facebook, students have difficulties to perceive Facebook as a tool supporting learning. Based on students' answers to the question of whether or not Facebook offers concrete, educational possibilities, three categories of students emerged: the 'indifferents', the 'approvers', and the 'supporters'. 10 out of 15 students did not see any educational possibility at all. This was exemplified in the way they answered this question; the students had to think a while before giving an answer, and their answer, moreover, tended to be very short. Thus, 10 interviewees were very concise with their answers on questions like the following:

Interviewer: 'Do you see opportunities to use Facebook in your studies in a certain way? Respondent 1: 'I really don't know actually.'

Interviewer: 'Do you see opportunities to use Facebook in higher education? Respondent 3: '( - -) Uhm, I don't know.'

Interviewer: 'Do you see overall educational opportunities of Facebook, to involve Facebook in higher education?

Respondent 9: 'Uhm, no, not really.'

Students apparently had not yet thought about - let alone discussed - the educational possibilities of Facebook, despite the observation that Facebook is extremely popular (see above) and that students increasingly apply computer applications (e.g., Microsoft Office, Photoshop, etc.) in educational activities (cf., Brown, 2010). This observation is quite remarkable, especially seen in the perspective of the current quest for online learning. Here, we can state that students do not want to use Facebook to achieve the competence of taking responsibility for their own study process. This first category of students, or the 'indifferents', is followed by a second group of students $(n=2)$ who acknowledge that Facebook has some educational possibilities, but they find it hard to point to concrete examples. We call them 'approvers': 
Interviewer: 'Do you see overall educational opportunities of Facebook, to involve it in higher education?'

Respondent 6: 'Uhm yes, that can probably be done. There are innumerable applications on Facebook but (does not finish the sentence).'

Interviewer: 'Do you see overall educational opportunities of Facebook?'

Respondent 5: 'Yeah, it could be educative in some way but I don't know how. At first sight, it seems hardly the medium to do so, to do educational affairs.'

Finally, taking a step further than the approvers, some students venture a tentative attempt to give educational possibilities of Facebook:

Respondent 3: 'But if it's possible, I see opportunities to use it as a forum or something. But not as the forum we use now on our Blackboard, because that is not widely used. Maybe this is due to the absence of constant updates, something that surely happens on Facebook.'

Respondent 5: 'You can make a Facebook group, that could be educational.'

Respondent 4: 'Yes, if all faculty members will be on Facebook and you could check their publications for example, that would be handy. If I could find an article about neurology for example, I would certainly read it.'

Because of their tendency to adopt possible educational applications on Facebook, this third category of students $(n=3)$ is further referred to as 'supporters'. In summary, we can state that most students had difficulties with giving examples of possible educational applications for Facebook in higher education.

Another finding that is true for the majority of the students is that students use firm distinctions between Facebook (for leisure time) on the one hand and virtual learning environments (e.g., Blackboard, for study time) on the other. After they thought about opportunities to implement (applications of) Facebook in higher education, soon students added some concerns. Several students indicated it would be regrettable to use Facebook for educational activities. Specifically, some students stated they use Facebook only for entertainment and do not want education-related activities to be incorporated (West et al., 2009):

Interviewer: 'Do you see opportunities to use Facebook in your studies in a specific way?'

Respondent 1: '(...) For me, I think you need to separate work and pleasure. But I don't know, I don't think Facebook can give an educational value.'

Interviewer: 'Are there any study-related documents passing by on Facebook or is it just for fun?'

Respondent 12: 'That's just for fun.'

Interviewer: 'Is Facebook used in terms of study, for example study-related documents?' Respondent 2: 'No, I don't think so, Facebook is just for fun. There are no study-related affairs involved.'

It seems Facebook is only used, at least by these respondents, during leisure time. Speaking in terms of reference group theory, for students Facebook is part of the culture of leisure time. Apparently, most respondents do not use Facebook for educational activities at all. However, despite this clear distinction concerning the reasons of their use, we must interpret these results with caution. Facebook as a communication tool is indeed sometimes used by students to send short, study-related messages. Those messages, however, do not influence students' study processes in a profound way, but deal with matters of organization of courses, giving news, etc. In other words, 
there are situations where the 'culture' can be breached in order to get a quick response from friends during the examinations period. Some quotes may illustrate this:

Interviewer: '(...) Do your peers use Facebook for educational purposes?'

Respondent 8: 'I think, especially after the exams, they just ask how it went.'

Interviewer: 'And when you are on Facebook, do you talk about your studies with peers?'

Respondent 9: 'Not really. I have received a message 'which elective are you going to take?' but that's all.'

As results shown above suggest, students, as represented by the so-called 'indifferents' category, preferably want to limit their Facebook usage to leisure activities, for example checking, sharing and tagging photographs with friends, posting wall posts on friends' walls, etc. Other participants also wish to use Facebook (mainly) for leisure time, but they can give some more or less concrete examples of how to use Facebook in education.

\section{Students' Perspectives towards Faculty Members' Presence and Privacy Issues on Facebook}

We summarize to what extent students are willing to accept friendships requests from faculty members (Malesky \& Peters, 2012; West et al., 2009). None of the interviewees would accept a friendship request from a faculty member (Madge et al., 2009; Roblyer et al., 2010). On the question 'What would you think if a faculty member sends you a friendship request on Facebook?' several respondents answered negatively:

Respondent 1: 'No, I would ignore that.'

Interviewer: 'Yes and why?'

Respondent 1: 'I don't know, if I don't know them, why should I add them? I mean, it's the same with other people, if I do not know them, I would not add them.'

Respondent 2: 'I think I would definitely ignore that pretty hard.'

Interviewer: 'Yes and why?'

Respondent 2: 'They don't have to know what I'm doing in my leisure time. Yeah, it depends which faculty member but I think I would refuse the vast majority.'

Respondent 3: 'I would absolutely say "No".'

Interviewer: 'Yes. And why?'

Respondent 3: 'Facebook is meant for talking with friends, with people I know. If someone adds me on Facebook and I don't know the name, the chance is certainly 90 per cent that I would just say 'no' because I don't know that person.'

Respondent 6: 'The chance that happens is very small of course, but I don't think I would accept.'

The reasons why students do not want to become Facebook friends with faculty members varied: some of them mentioned they only wanted (to have) 'real' friends on Facebook, others were more afraid of a possible incursion in one's privacy: 'They don't have to know what I'm doing in my leisure time' (Respondent 2). In our view, role theory, and more exactly a role conflict, can explain these students' refusal. Indeed, it seems there is a mismatch of expectations within the students' role. Based on their social position, it is no surprise that students are Facebook members primarily to stay in contact with their friends: 'The only people I have on Facebook, I want to know them' (Respondent 5), but at the same time, based on the same social position as students, students experience that being a faculty member's friend is not one of their expectations. '(...) 
Yes, I will ignore teaching assistants too. How old are they, ten years older? Or maybe five? But no, these are no friends either' (Respondent 4).

Like Hewitt and Forte (2006) and Malesky and Peters (2012), we asked the respondents whether it is acceptable for faculty members to get a profile on Facebook. Students' perceptions were unanimously positive: 'Yes, why not? Faculty members are people too, don't you think?' (Respondent 1). 'Oh, I don't have problems with that. They have their own life, they must do what they like to do' (Respondent 2). It seems students allow faculty members' presence on Facebook, as long as they do not become part of students' friend lists.

We also investigated to what extent students are cautious about their Facebook usage. West et al. (2009) already indicated that some of them pay attention to an excessive self-disclosure of messages and photographs on their profile. With respect to this research, students give several reasons for this avoidance of too much self-disclosure:

Interviewer: 'Is it dangerous somehow?'

Respondent 7: 'Dangerous is not the word, but for example: my parents are on Facebook too and when I'm drunk at a party and there are pictures, than I would have to justify myself.'

Respondent 15: 'I've got a girlfriend who really likes taking photographs and I have to be careful because my uncle is on Facebook too, and he must not see everything that we 're doing.'

Respondent 4: 'I think it's dangerous, especially when you're looking for a job. I think they'll check your Facebook profile. For example, I want to work for ... [catering company] and I think they'll screen you on Facebook. I think that would be the case.'

Apparently, students are very aware of potential pitfalls of disclosing too much personal information on their profile, which every friend or contact can see. Our findings show a clear pattern here; faculty are not allowed to be friends with students, based on a strong distinction between school and leisure time on the one hand and a strong awareness of the consequences of too much self-disclosure on the other. Reference group theory suggests an explanation. We can observe two reference groups: students and faculty members. For students, this distinction should be kept. Faculty members are not part of students' private lives and in this vein we can situate the observation of students' refusal to accept friendship requests of faculty members. In other words, students regard their faculty members partly as a positive reference group; this means that students only want to be judged in respect to their study-related behavior.

\section{Discussion and Implications}

Before giving our theoretical explanations of our main results, we should make some reflections about our theoretical background and the conducted methodology. As already highlighted, our respondents were all bachelor degree students of one particular university. More specifically, all respondents were students who attended their second year at the university. These students were selected because they had already passed their period of adaptation to a totally new environment. Therefore we may assume that our results adequately reflect their actual daily ICT use. This would not have been guaranteed by taking a sample of freshmen. Moreover, we must not forget that the data, both from the Web surveys and the interviews, were reported by the respondents themselves. However it was stressed that all data was anonymously collected and analyzed, we should keep in mind that respondents might have given answers they thought they were expected by the researchers. During the in depth interviews it was possible to control this, but this is less evident in the Web surveys. The respondents were told to fill in the Web surveys as soon as pos- 
sible in order to get very precise results, but this might still not totally exclude a social desirability bias.

In relation to that, we must recognize that probably only students possessing a PC or laptop filled in the Web surveys. But this should be put in a correct context. From other research we know that most of the students of this university have a PC or laptop and that there are a lot of places where all students have access to PCs. After all, the Web surveys were sent by e-mail and we can suppose that the respondents were using their PC or laptop, both for private and educational reasons, at least as much as other students.

As already explained in the data analysis, we decided not to merge the results of both Web surveys due to significant differences concerning gender and faculty. In this respect, we are fully aware that our data do not allow any further explanation in what way these variables could explain an eventually different ICT use (as recently found by, for example Kubiatko, Yilmaz, \& Halakova, 2012).

Finally, we have some thoughts about the low response rate. Experienced researchers know that it is not easy to find respondents when these respondents have to engage for more than one meeting or for answering more than one questionnaire. In order to collect valid and reliable data that would be closely connected with all moments of the use of SNSs, PCs, and the like during an academic year we asked from the in depth interviewees an engagement for four meetings in a period of eight months.. These high demands have certainly influenced the response rate. Further research will show whether our observations will be refuted.

Our results showed students almost exclusively use Facebook for daily activities (tagging photos, communicating with friends, passing time). Despite this popularity, students barely use Facebook for educational purposes. This is in line with Selwyn (2009), who analyzed 909 Facebook 'walls' of undergraduate students in a UK university and concluded that "education- and universityrelated exchanges were only a minor constituent of the overall volume..." (p. 170). Furthermore, Selwyn (2009) found that education-related interactions between students on Facebook happened more in times of assessment. In other words, students did not experience a desire for (forms of) continuous learning on Facebook. The same refusal by students was found in other research by Manca and Ranieri (2013): “...they (students) were not at ease with using it (Facebook) for traditional courses" (p. 7). And, based on a critical analysis of 23 research projects, they concluded that: “...there are still many obstacles that may prevent a full adoption of Facebook as a learning environment..." (p. 1).

This is clearly in contrast with the results of the study of Mazman and Usluel (2010). Without going into a high level of detail of their research, they found that Facebook use in daily activities is closely related with its educational utilization. Yu, Tian, Vogel, and Kwok (2010), on the other hand, stress that online social networking is positive for peer relationships and acceptance by peers, and this "promote[s] learning outcomes" (p. 1500). With these results and the aim of this article in mind, we try to frame our findings within role theory and reference group theory. In our view, these theories give us three explanations of the results obtained.

A first explanation of students' denial to accept faculty members as Facebook friends may be the incursion of one's privacy. Some respondents directly related their refusals to accept friendship requests from faculty members and to put photographs online to this privacy issue. Similar results are found by West et al. (2009), who interviewed a sample of 16 students. They found that only one of them had their mother as a Facebook friend. They concluded, "The reasons for not wanting older adults, and particularly parents, as friends appeared to be related to embarrassment, social norms, and worries about mothers being exposed and made vulnerable. Underlying these reasons are various notions of privacy" (p. 624). Connell (2009) conducted research concerning libraries using Facebook and MySpace as outreach tools for students. Based on a survey among 366 Val- 
paraiso University freshmen, she recommended that librarians proceed with caution if they wished to use Facebook or MySpace as a support tool. She found that 12\% reacted negatively due to a possible incursion upon one's privacy. Similar results were found in the research of Chu and Meulemans (2008), Selwyn (2009) and Madge et al. (2009). Those examples seem to show that students identify themselves with different reference groups, depending on the circumstances in which they are situated.

A second explanation as to why students refuse faculty members as Facebook friends can be found in reference group theory. As far as Facebook is concerned, some students in our research indicated that they created a Facebook account because "everyone has one". This kind of imitation can be explained by the behavior of one person being consistent with the expectations of the peer group. As students indicated, when a person has no Facebook account, they get excluded from peers and invitations to parties. In our view, this points out that a 'reference group', for example the peer group, is highly context-specific; peers can be a positive (and negative) reference group. This is also shown in the study of the use of a medical Facebook site by medical students in Nepal by Pimmer et al. (2012). In this resource-limited environment, these students found in this site a support for "expression of professional identity, belonging to and participation in professional communities".

A third explanation can be found in role theory. We can state that students do not tolerate faculty members as virtual friends (above cited as a role conflict). In other words, being a faculty member's friend cannot be reconciled with the role as a student. In our view, this explanation also explains, for example, the results found by West et al. (2009), stating that adolescents reveal how they see that role. Indeed, West et al. (2009) found adolescents do not want their parents as Facebook friends.

Nevertheless, and in line with Selwyn (2009), we can conclude that Facebook use is an important part of 'being' a student. Although the students who participated in this research were not able to sum up concrete educational possibilities of Facebook, this SNS is undoubtedly a (virtual) space where they can develop a social identity. In other words, and more in line with role theory, by using Facebook, students learn the ability to distance themselves from the roles they should include in society (e.g., to conform oneself to the existing hierarchical relationship, etc.); in this way they can experience a role-conflict. It may be that dealing with these kinds of role conflicts could be Facebook's greatest educational possibility.

Our recommendation is - to meet some intended learning outcomes of KU Leuven - that faculty members become aware of the possibilities SNSs entail to (possibly) cause a role conflict in students' life. The way in which students communicate on SNSs - and students' refusal to accept faculty members as Facebook friends is not surprising in this regard - seems to be very different than the language students use on (university provided) discussion boards (e.g., Blackboard). As already mentioned in the results section, some students give some conditions to be taken into account when using Facebook as an educational tool: it can be used as a forum where they can discuss practical or more content-related things. Another possibility that was proposed is to create a private group. Faculty members should not be allowed to be a member of it. It is up to the students to decide who can be a member of the group (Manca \& Ranieri, 2013; Selwyn, 2009).

\section{Conclusions}

In this article, aiming to demonstrate how role theory and reference group theory (possibly) explain daily ICT use by students, we confirmed the enormous popularity of SNSs amongst contemporary students. Around $83 \%$ of the respondents have a Facebook account. The most important reason why students spend time on Facebook is to maintain contact with friends. Results also showed that students have difficulties perceiving Facebook as a tool supporting learning. In gen- 
eral, students make a clear distinction between ICT use for study and non-study related purposes. More particularly, three categories of students arise concerning students' answers on the question of whether Facebook possesses educational possibilities: the indifferents, the approvers, and the supporters. None of the respondents would accept a friendship request from a faculty member. In the discussion and implications section, we tried to explain these results using role theory and reference group theory.

In conclusion, our directions for future research are at the same time the biggest limitations of this study. First, a larger number of respondents could lead towards more common conclusions concerning the daily ICT use of today's students. Furthermore, the rising number of portable internetready applications (e.g., notebook, tablets, laptop, etc.) could lead towards a higher level of studyrelated ICT use, especially during the lessons. Finally, this article tries to make a start upon combining these educational practices with more socially-inspired theories. We hope future research will bring more insight as to whether or not sociological theories can (at least partly) define students' study-related use of ICT applications.

\section{References}

Anderson, P. (2007). What is Web 2.0? Ideas, technologies and implications for education. Retrieved from http://www.jisc.ac.uk/media/documents/techwatch/tsw0701b.pdf

Anderson, T., \& Dron, J. (2011). Three generations of distance education pedagogy [Electronic version]. The International Review of Research in Open and Distance Learning, 12(3), 80-97.

Bazeley, P. (2007). Qualitative data analysis with NVivo. London, United Kingdom: Sage.

Biddle, B. J., \& Thomas, E. J. (1966). Role theory: Concepts and research. New York, NY: John Wiley.

Boyd, D. M. (2008). Why youth heart social network sites: The role of networked publics in teenage social life. In D. Buckingham (Ed.), Youth, identity, and digital media (pp. 119-142). Cambridge, MA: MIT Press.

Boyd, D. M., \& Ellison, N. B. (2007). Social network sites: Definition, history, and scholarship. Journal of Computer-Mediated Communication, 13, 210-230. doi:10.1111/j.1083-6101.2007.00393.x

Boyd, D. M., \& Hargittai, E. (2010). Facebook privacy settings: Who cares? First Monday, 15. Retrieved from http://www.uic.edu/htbin/cgiwrap/bin/ojs/index.php/fm/article/view/3086/2589

BrainyQuote. (2010). Definition of willingness. Retrieved from http://www.brainyquote.com/words/wi/willingness239927.html

Brown, S. (2010). From VLEs to learning webs: The implications of Web 2.0 for learning and teaching. Interactive Learning Environments, 18(1), 1-10.

Bugeja, M. J. (2006). Facing the Facebook. Chronicle of Higher Education, 52(21), C1.

Cassidy, J. (2006, May 15). Me media. How hanging out on the Internet became big business. The New Yorker, 50-59.

Chu, M., \& Meulemans, Y. N. (2008). The problems and potential of MySpace and Facebook usage in academic libraries. Internet Reference Services Quarterly, 13(1), 69-85. doi:10.1300/J136v13n01_04

CMU (Central Michigan University). (2010). CMU researcher explores Facebook's privacy dangers for teens [Video file]. Retrieved from http://www.youtube.com/watch?v=U7ER0KCxgac

Connell, R. S. (2009). Academic libraries, Facebook and MySpace, and student outreach: A survey of student opinion. Libraries and the Academy, 9(1), 25-36.

Cuban, L. (1986). Teachers and machines: The classroom use of technology since 1920. New York, NY: Teachers College Press. 
Dahrendorf, R. (1968). Homo Sociologicus: On the history, significance, and limits of the category of social role. In R. Dahrendorf (Ed.), Essays in the theory of society (pp. 19-87). London, United Kingdom: Routledge \& Kegan Paul.

Denzin, N. K. (1970). Triangulation: A case for methodological evaluation and combination. Introduction. In N. K. Denzin (Ed.), Sociological methods (pp. 471-475). Chicago, IL: Aldine.

Denzin, N. K. (1978). The Research Act. A theoretical introduction to sociological methods. New York, NY: McGraw-Hill Book Company.

De Wit, J., Van Der Veer, G., \& Slot, N. W. (2005). Psychosociale ontwikkeling: Leeftijdgenoten, school, werk en vrije tijd [Psycho-social development: Peers, school, work, and leisure]. In J. De Wit, G. Van Der Veer, \& N. W. Slot (Eds.), Psychologie van de adolescentie [Psychology of the adolescence] (pp. 99-144). Baarn, The Netherlands: HB Uitgevers.

De Wit, K., Heerwegh, D., \& Verhoeven, J. C. (2012). Do ICT competences support educational attainment at university? Journal of Information Technology Education: Research, 11, 1-25. Retrieved from http://www.jite.org/documents/Vol11/JITEv11p001-025DeWit1037.pdf

Doughtery, H. (2010, March 15). Facebook reaches top ranking in US [Web log post]. Retrieved from http://weblogs.hitwise.com/heather-dougherty/2010/03/facebook_reaches_top_ranking_i.html

Facebook. (2010). Perskamer [Press room]. Retrieved from http://www.facebook.com/\#!/press/info.php?statistics

Facebook. (2011). Find friends. Retrieved from http://www.facebook.com/find-friends/?ref=pf

Fogel, J., \& Nehmad, E. (2009). Internet social network communities: Risk taking, trust, and privacy concerns. Computers in Human Behavior, 25(1), 153-160. doi:10.1016/j.chb.2008.08.006

Greenhow, C. (2011). Online social networks and learning. On the Horizon, 19(1), 4-12.

Halverson, E. R. (2011). Do social networking technologies have a place in formal learning environments? On the Horizon, 19(1), 62-67.

Hammersley, M. (1996). The relationship between qualitative and quantitative research: Paradigm loyalty versus methodological eclecticism. In T. E. Richardson (Ed.), Handbook of research methods for psychology and the social sciences (pp. 159-174). Leicester, United Kingdom: BPS Books.

Hewitt, A., \& Forte, A. (2006, November). Crossing boundaries: Identity management and student/faculty relationships on the Facebook. Poster presented at the CSCW, Banff, Canada.

Hindin, M. J. (2007). Role theory. Retrieved from http://www.blackwellreference.com/subscriber/uid=56/tocnode?query=hindin\&widen=1\&result numb

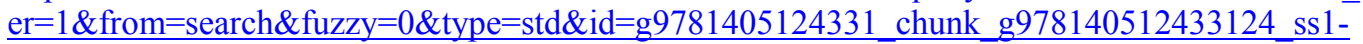
$\underline{78 \& \text { slop }=1}$

Hinduja, S., \& Patchin, J. W. (2008). Personal information of adolescents on the internet: A quantitative content analysis of MySpace. Journal of Adolescence, 31, 125-146.

doi:10.1016/j.adolescence.2007.05.004

Hirschorn, M. (2007, October). About Facebook. Retrieved from http://www.theatlantic.com/magazine/archive/2007/10/about-facebook/6181/

Jones, C., Ramanau, R., Cross, S., \& Healing, G. (2010). Net generation or digital natives: Is there a distinct new generation entering university? [Electronic version]. Computers \& Education, 54, 722-732. Doi:10.1016/j.compedu.2009.09.022

Judd, T., \& Kennedy, G. (2010). A five-year study of on-campus Internet use by undergraduate biomedical students. Computers \& Education, 55, 1564-1571. doi:10.1016/j.compedu.2010.06.022

Kabilan, M. K., Ahmad, N., \& Abidin, M. J. Z. (2010). Facebook: An online environment for learning of English in institutions of higher education? [Electronic version]. Internet and Higher Education, 13, 179-187. doi:10.1016/j.iheduc.2010.07.003 
Kirschner, P. A., \& Karpinski, A. C. (2010). Facebook ${ }^{\circledR}$ and academic performance. Computers in Human Behavior, 26(6), 1237-1245. doi:10.1016/j.chb.2010.03.024

Kubiatko, M., Yilmaz, H., \& Halakova, Z. (2012). The attitudes of Slovak and Turkish high school students to the ICT used in biology according to gender and age differences [Abstract]. Social and Educational Studies, 4(1), 433-446.

KU Leuven. (2009). K.U.Leuven's vision of teaching and learning. Translation of "Visie op onderwijs en leren" approved by the Academic Council d.d. 16/11/2009. Retrieved April 10, 2013, from http://www.kuleuven.be/education/KULeuven-Vision_of teaching and learing-2009.pdf

Lee, M. J. W., \& McLoughlin, C. (2008). Harnessing the affordances of Web 2.0 and social software tools: Can we finally make "student-centered" learning a reality? In J. Luca \& E. Weippl (Eds.), Proceedings of World Conference on Educational Multimedia, Hypermedia and Telecommunications 2008 (pp. 3825-3834). Chesapeake, VA: AACE. Retrieved from http://www.editlib.org/p/28915

Lenhart, A., \& Madden, M. (2007). Social networking websites and teens. Retrieved from http://www.pewinternet.org/Reports/2007/Social-Networking-Websites-and-Teens.aspx

Lenhart, A., Purcell, K., Smith, A., \& Zickuhr, K. (2010). Social media \& mobile Internet use among teens and young adults. Retrieved from http://pewresearch.org/pubs/1484/social-media-mobile-internet-useteens-millennials-fewer-blog

Lynch, K. D. (2007). Modeling role enactment: Linking role theory and social cognition. Journal for the Theory of Social Behaviour, 37(4), 379-399.

Madge, M., Meek, J., Wellens, J., \& Hooley, T. (2009). "Facebook", social integration and informal learning at the university: "It is more for socialising and talking to friends about work than for actually doing work". Learning, Media and Technology, 34(2), 141-155.

Malesky, L. A., \& Peters, C. (2012). Defining appropriate professional behavior for faculty and university students on social networking sites. International Journal of Higher Education and Educational Planning, 63(1), 135-151. doi:10.1007/s10734-011-9451-x

Manca, S., \& Ranieri, M. (2013). Is it a tool suitable for learning? A critical review of the literature on Facebook as a technology-enhanced learning environment. Journal of Computer Assisted Learning, 118. doi:10.1111/jcal.12007

Mason, R., \& Rennie, F. (2008). E-learning and social networking handbook. Resources for higher education. New York, NY: Routledge.

Mazer, J. P., Murphy, R. E., \& Simonds, C. J. (2007). I'll see you on "Facebook": The effects of computermediated teacher self-disclosure on student motivation, affective learning, and classroom climate. Communication Education, 56(1), 1-17. doi:10.1080/03634520601009710

Mazman, S. G., \& Usluel, Y. K. (2010). Modeling educational usage of Facebook. Computers \& Education, 55(2), 444-453. doi:10.1016/j.compedu.2010.02.008

Mead, G. H. (1964). On social psychology. Chicago, IL: The University of Chicago Press.

Merton, R. K., \& Lazarsfeld, P. F. (1950). Continuities in social research: Studies in the scope and method of 'the American soldier'. New York, NY: The Free Press.

Minocha, S., Schroeder, A., \& Schneider, C. (2011). Role of the educator in social software initiatives in further and higher education: A conceptualisation and research agenda. British Journal of Educational Technology, 42(6), 889-903. doi:10.1111/j.1467-8535.2010.01131.x

Mirande, A. M. (1968). Reference group theory and adolescent sexual behavior. Journal of Marriage and the Family, 30(4), 572-577.

Pasek, J., More, E., \& Hargittai, E. (2009). Facebook and academic performance: Reconciling a media sensation with data. First Monday, 14(5). Retrieved from http://www.uic.edu/htbin/cgiwrap/bin/ojs/index.php/fm/article/view/2498/2181 
Pempek, T. A., Yermolayeva, Y. A., \& Calvert, S. L. (2009). College students' social networking experiences on Facebook. Journal of Applied Developmental Psychology, 30(3), 227-238.

Perkins, K. K., \& Turpen, C. (2009). Student perspectives on using clickers in upper-division physics courses. Retrieved September 20, 2010, from http://www.cwsei.ubc.ca/SEI research/files/Physics/Perkins_StudentPerpectivesOnUsingClickersL.pd $\underline{f}$

Pimmer, C., Linxen, S., \& Gröhbiel, U. (2012). Facebook as learning tool? A case study on the appropriation of social network sites from mobile phones in developing countries. British Journal of Educational Technology, 43(5), 726-738. doi: 10.1111/j.1467-8535.2012.01351.x

Raynes-Goldie, K. (2010). Aliases, creeping, and wall cleaning: Understanding privacy in the age of Facebook. First Monday, 15. Retrieved from http://firstmonday.org/htbin/cgiwrap/bin/ojs/index.php/fm/article/view/2775/2432

Roblyer, M. D., McDaniel, M., Webb, M., Herman, J., \& Witty, J. V. (2010). Findings on Facebook in higher education: A comparison of college faculty and student uses and perceptions of social networking sites. Internet and Higher Education, 13(3), 134-140. doi:10.1016/j.iheduc.2010.03.002

Sandars, J., \& Schroter, S. (2007). Web 2.0 technologies for undergraduate and postgraduate medical education: An online survey. Postgraduate Medical Journal, 83, 759-762. doi:10.1136/pgmj.2007.063123

Sellers, P. (2006). MySpace cowboys. Retrieved April 30, 2010, from http://money.cnn.com/magazines/fortune/fortune archive/2006/09/04/8384727/index.htm

Selwyn, N. (2007). 'Screw Blackboard... do it on Facebook!': An investigation of students' educational use of Facebook [Electronic version]. Retrieved from http://www.scribd.com/doc/513958/Facebookseminar-paper-Selwyn

Selwyn, N. (2009). Faceworking: Exploring students' education-related use of Facebook. Learning, Media and Technology, 34(2), 157-174. doi:10.1080/17439880902923622

Shibutani, T. (1986). Social Processes. An introduction to sociology. Berkeley, LA: University of California Press.

Socialbakers. (2012). Facebook statistics by country. Retrieved from http://www.socialbakers.com/facebook-statistics/

Tufekci, Z. (2008). Grooming, gossip, Facebook and Myspace. What can we learn about these sites from those who won't assimilate? Information, Communication and Society, 11(4), 544-564. doi:10.1080/13691180801999050

van Dijk, J. A. G. M. (2006). Digital divide research, achievements and shortcomings. Poetics, 34(4-5), 221-235. doi:10.1016/j.poetic.2006.05.004

Waters, S., \& Ackerman, J. (2011). Exploring privacy management on Facebook: Motivations and perceived consequences of voluntary disclosure. Journal of Computer-Mediated Communication, 17, 101115. doi:10.1111/j.1083-6101.2011.01559.x

West, A., Lewis, J., \& Currie, P. (2009). Students' Facebook "friends": Public and private spheres. Journal of Youth Studies, 12(6), 615-627.

Yu, A. Y., Tian, S. W., Vogel, D., \& Kwok, R. C. (2010). Can learning be virtually boosted? An investigation of online social networking impacts. Computers \& Education, 55(4), 1494-1503. doi:10.1016/j.compedu.2010.06.015

Zydney, J. M. (2008). Cognitive tools for scaffolding students defining an ill-structured problem. Journal of Educational Computing Research, 38(4), 353-385. 


\section{Biographies}

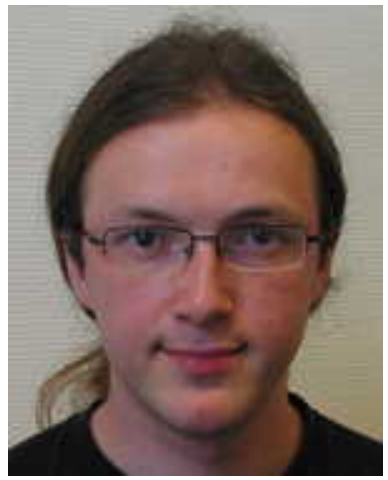

Steven Bruneel is a project collaborator at the Centre for Instructional Psychology and Technology at the University of Leuven, Belgium. His main research is about students' use of social media, and ICT in general, in their study process. His current research interests include the roles of e-learning objects in (higher) education and the use of social media in (higher) education.

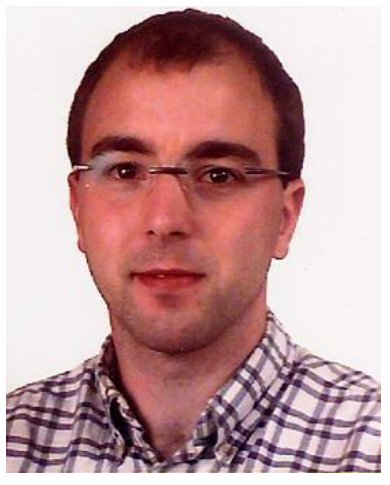

Kurt De Wit, $\mathrm{PhD}$ in Sociology, is head of the Data Management Unit of the Education and Teaching Department at the University of Leuven (Belgium). He carries out institutional research on students and education and monitors national and European higher education policy. $\mathrm{He}$ serves on the Executive Council of the Flemish Sociological Association and is editor-in-chief of its peer-reviewed journal (Tijdschrift voor Sociologie). His current research interests include education innovation policy in higher education, the roles of ICT for university students, international rankings of higher education institutions, governance and funding of higher education, and the development of the network society and its consequences for higher education.

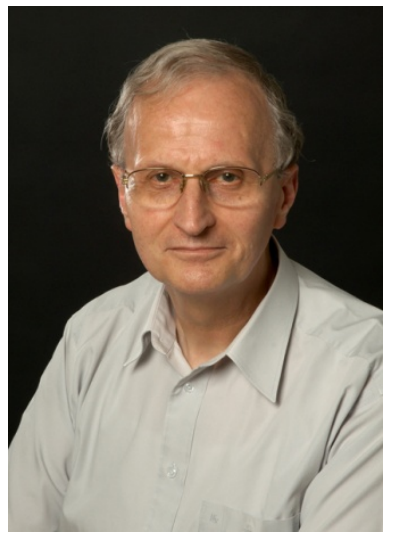

Jef C. Verhoeven is emeritus professor of sociology at the University of Leuven (Belgium). His recent research is focused on students' orientation toward scientific research in higher education and the use of ICT. He taught at several universities abroad (see https://perswww.kuleuven.be/ u0003309/School/EducationAndTheory indexhoogGuestE css.html) and published in the fields of theoretical sociology and sociology of education including many books, and articles in, among others, European Journal of Education, Journal of Education Policy, Educational Management, Administration \& Leadership, Higher Education Policy, Teacher Development, Research on Language and Social Interaction, Studies in Higher Education, Education Policy Analysis Archives, Tsinghua Journal of Education, Teachers and Teaching, Journal of Shandong University (Philosophy and Social Sciences), Assessment in Education: Principles, Policy \& Practice, Computers \& Education, Frontiers of Education in China, Education and Information Technologies, Diaspora, Indigenous, and Minority Education, Journal of Information Technology Education: research (JITE: Research). 


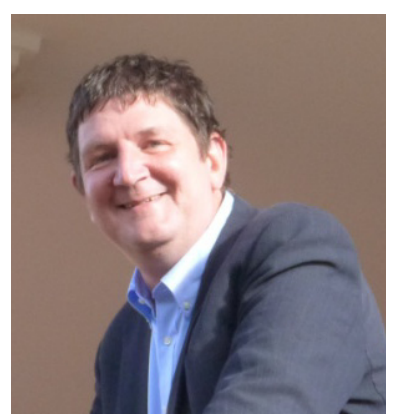

Jan Elen is a professor of instructional psychology and educational technology at the University of Leuven (Belgium) and the current vice dean education of the Faculty of Psychology and Educational Sciences. His recent research is focused on the relationship between research and teaching in higher education, the use of electronic learning environments by students, the development of critical thinking, and the potential of educational games for teaching mathematics to vocational students. He is the current senior editor of Instructional Science and has published in, among others, Studies in Higher Education, Higher Education, Educational Technology Research and Technology, Computers \& Education, Journal of Educational Technology and Society, Curriculum Studies, British Journal of Educational Technology. He teaches undergraduate and graduate course on instructional psychology, educational technology and instructional design. 